2014s-03

\title{
Income Growth, Inequality and Poverty Reduction: A Case Study of Eight Provinces in China
}

\author{
Chor-ching Goh, Xubei Luo, Nong Zhu
}

\begin{tabular}{c}
\hline Série Scientifique \\
Scientific Series
\end{tabular}

\author{
Montréal \\ Janvier/January 2014
}

(C) 2014 Chor-ching Goh, Xubei Luo, Nong Zhu. Tous droits réservés. All rights reserved. Reproduction partielle permise avec citation du document source, incluant la notice (C).

Short sections may be quoted without explicit permission, if full credit, including (C) notice, is given to the source.
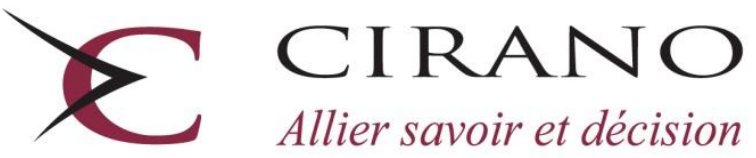

Allier savoir et décision

Centre interuniversitaire de recherche en analyse des organisations 


\section{CIRANO}

Le CIRANO est un organisme sans but lucratif constitué en vertu de la Loi des compagnies du Québec. Le financement de son infrastructure et de ses activités de recherche provient des cotisations de ses organisations-membres, d'une subvention d'infrastructure du Ministère de l'Enseignement supérieur, de la Recherche, de la Science et de la Technologie, de même que des subventions et mandats obtenus par ses équipes de recherche.

CIRANO is a private non-profit organization incorporated under the Québec Companies Act. Its infrastructure and research activities are funded through fees paid by member organizations, an infrastructure grant from the Ministère de l'Enseignement supérieur, de la Recherche, de la Science et de la Technologie, and grants and research mandates obtained by its research teams.

\section{Les partenaires du CIRANO}

\section{Partenaire majeur}

Ministère de l'Enseignement supérieur, de la Recherche, de la Science et de la Technologie

\section{Partenaires corporatifs}

Autorité des marchés financiers

Banque de développement du Canada

Banque du Canada

Banque Laurentienne du Canada

Banque Nationale du Canada

Banque Scotia

Bell Canada

BMO Groupe financier

Caisse de dépôt et placement du Québec

Fédération des caisses Desjardins du Québec

Financière Sun Life, Québec

Gaz Métro

Hydro-Québec

Industrie Canada

Investissements PSP

Ministère des Finances et de l'Économie

Power Corporation du Canada

Rio Tinto Alcan

State Street Global Advisors

Transat A.T.

Ville de Montréal

\section{Partenaires universitaires}

École Polytechnique de Montréal

École de technologie supérieure (ÉTS)

HEC Montréal

Institut national de la recherche scientifique (INRS)

McGill University

Université Concordia

Université de Montréal

Université de Sherbrooke

Université du Québec

Université du Québec à Montréal

Université Laval

Le CIRANO collabore avec de nombreux centres et chaires de recherche universitaires dont on peut consulter la liste sur son site web.

Les cahiers de la série scientifique (CS) visent à rendre accessibles des résultats de recherche effectuée au CIRANO afin de susciter échanges et commentaires. Ces cahiers sont écrits dans le style des publications scientifiques. Les idées et les opinions émises sont sous l'unique responsabilité des auteurs et ne représentent pas nécessairement les positions du CIRANO ou de ses partenaires.

This paper presents research carried out at CIRANO and aims at encouraging discussion and comment. The observations and viewpoints expressed are the sole responsibility of the authors. They do not necessarily represent positions of CIRANO or its partners. 


\title{
Income Growth, Inequality and Poverty Reduction: A Case Study of Eight Provinces in China*
}

\author{
Xubei Luo ${ }^{\dagger}$, Chor-ching Goh ${ }^{+}$, Nong Zhu ${ }^{\S}$
}

\begin{abstract}
Résumé/abstract
This paper examines the growth performance and income inequality in eight Chinese provinces during the period of 1989-2004 using the China Health and Nutrition Survey data. It shows that income grew for all segments of the population, and as a result, poverty incidence has fallen. However, income growth has been uneven, most rapidly in coastal areas, and among the educated. A decomposition analysis based on household income determination suggests that income growth can largely be attributed to the increase in returns to education and to the shift of employment into secondary and tertiary sector.
\end{abstract}

Mots clés : Income growth, Inequality, Poverty, China.

Codes JEL : O15, O53, P36

\footnotetext{
* This article was published in China Economic Review, vol. 20, no. 3, p. 485-496.

${ }^{\dagger}$ Senior economist, The World Bank, East Asia and Pacific Region, Poverty Reduction and Economic Management Department, cgoh@worldbank.org

$¥$ Senior economist, The World Bank, East Asia and Pacific Region, Poverty Reduction and Economic Management Department, xluo@worldbank.org

${ }^{\S}$ INRS-UCS, University of Quebec. Corresponding author: INRS-UCS, 385 rue Sherbrooke Est, Montreal, QC, H2X 1E3, Canada. Tel: 1-514-499-8281. Fax.: 1-514-499-4065. Nong.Zhu@UCS.INRS.Ca
} 


\section{Introduction}

The growth performance of the Chinese economy in the past decades has been spectacular with an annual per capita growth rate of about $9 \%$ since 1990. Overall living standards in China have improved significantly with rapid poverty reduction (Chen and Ravallion, 2007; 2008). However, growth has been uneven - rising rural-urban inequality and coastal-inland gap have been documented in many studies (Chaudhuri and Ravallion, 2006; Chen and Wang, 2001; Chotikapanich et al., 2007; Khan and Riskin, 2001; Ravallion and Chen, 2007; Wade, 2004; Wan et al., 2006; 2007). Not everyone has shared the success equally. Dismantlement of the commune system in rural areas and large-scale economic restructuring of state and collective sectors in urban areas changed the foundations of Chinese social welfare system. The benefits of new mechanism to ensure social equity and stability are yet to be harnessed. Understanding the roles of economic growth and income distribution in China's extraordinary success in reducing poverty within a generation is of great interest.

There is a rich literature on changes in income distribution in China since the economic reform. Some studies focus on inequality between rural and urban areas and between coastal and inland areas (see for instance Gustafsson and Li, 2002; Kanbur and Zhang, 1999; Lu, 2002; Renard, 2002; Sicular et al., 2007; Tsui, 1991; 2007, Yu et al., 2007). Some other studies examine the impact of governmental policies on inequality (Fan et al., 2002; Heerink et al., 2006). More recently, attention is being turned to the relative importance of contributing factors of inequality and poverty (Wan, 2007). These studies look into decompositions based on micro-analyses at the disaggregated levels of counties, villages, households and even individuals (Meng et al., 2007; Wan, 2004; Wan and Zhou, 2005; Zhang and Wan, 2006). 
This paper contributes to the literature by using household level information to analyze (i) the evolution of rural and urban household income in coastal and inland provinces; (ii) the extent of poverty reduction; and (iii) the factors behind income growth. We show how uneven growth affected inequality in different parts of China and examine the major determinants of income growth. The structure of the paper is as follows. Section 2 presents the data; section 3 reviews the literature on inequality and poverty in China since the economic reforms. Section 4 presents the empirical methodology; section 5 discusses the results, and section 6 concludes.

\section{Data}

We use the China Health and Nutrition Survey (CHNS), a longitudinal survey with six waves in 1989, 1991, 1993, 1997, 2000 and 2004. Li and Zhu (2006) and Zhang and Wan (2006) used a part of this dataset in their analysis of income inequality in China. This data collection is an ongoing international collaborative project among the Carolina Population Center at the University of North Carolina at Chapel Hill, the National Institute of Nutrition and Food Safety, and the Chinese Center for Disease Control and Prevention. ${ }^{1}$ The sample of households was randomly drawn from eight provinces including Liaoning, Shandong, Jiangsu, Henan, Hubei, Hunan, Guangxi and Guizhou. ${ }^{2}$ These provinces vary by geography and economic development, and can be considered as regionally representative. Four neighborhoods in each city, one countytown neighborhood, and three villages in each county, were then randomly selected.

\footnotetext{
${ }^{1}$ A detailed description of the data can be obtained from http://www.cpc.unc.edu/china/.

${ }^{2}$ Liaoning was replaced by Heilongjiang in the round of 1997 and returned to the survey in 2000.
} 
Approximately 20 households were sampled per community. With each consecutive wave of the survey, Newly-formed households who resided in sample areas and additional households that replace those no longer participating were added to the sample. New communities were also added to replace communities no longer participating.

In this study, we use the 1989 and 2004 survey data to analyze changes in real income. ${ }^{3}$ We classify Jiangsu, Liaoning, and Shandong as coastal provinces and the rest as inland provinces. The 1989 round included 3795 households or 10664 adults (18 years of age or older). The 2004 round included 3810 households or 9856 adults. The variables of interest examined in this study include the standard human capital variables of the head and other adults of the household (e.g., age; schooling; occupations; and type of employers) and location of the household. In addition, among rural households, the amount of farmland and type of non-farm activity are included.

\section{Changes in inequality and poverty in China}

The changes in income distribution have been closely associated with the evolution of reform focus. In the mid/late-1980s, full employment or the so called "iron rice bowl" policy (tie fan wan) came to an end as State-Owned-Enterprises (SOEs) restructuring took center stage during

\footnotetext{
${ }^{3}$ We thank the anonymous referee for pointing out the potential problems in the CPI series derived in the CHNS dataset. We use two series of price indices to adjust household income and our results are robust to both First, income is adjusted to 1988 urban Liaoning price using retail price indices based on the CHNS dataset. Second, urban-rural provincial CPI from China Statistical Yearbook is used. This paper only reports the results based on the China Statistical Yearbook's CPI series to avoid the issue of reliability of the CHNS-based price series. Please see Chen et al. (2007) for a discussion of the price series.
} 
the1990s reform. Profitable firms increased wages for skilled or able workers while laying off the less qualified. In addition to the resulting rise in income inequality, poverty also became an urban issue (Wang et al., 2002; Wu, 2004). Fang et al. (2002), using the 1992-1998 urban household surveys, find that urban poverty incidence declined between 1992 and 1995, but increased from 1996 to 1998 . Results on changes in poverty over time are sensitive to poverty lines chosen and index employed (Bishop et al., 2006). Using province-year grouped data, Chotikapanich et al. (2007) study the nature and extent of inequality in rural and urban China over the period 1978 to 2002. Their results show that inequality in rural China has been slightly higher than in urban China. However, inequality in urban China has increased so rapidly in recent years that it may soon surpass that of rural China. Meng et al. (2005), using household survey data from 1986 to 2000, suggest that urban poverty increased in the 1990s because the costs of education, housing, and health care, previously provided free of charge or highly subsidized by the state, went up as economic reforms deepened. Meng et al. (2007) find that large households and households with dependents are more likely to be poor, which is consistent with the change from subsidy-based to fee-based services.

In rural areas, Zhang and Wan (2006) find that agriculture-led growth raised rural income, improved income distribution, and reduced rural poverty in the late 1980s; however, in the 1990s, the impact of growth on poverty reduction was much smaller. Similar findings were also observed by Meng et al. (2005) who examined the effects of inequality and income on poverty reduction. Wan and Zhou (2005) find that while geography has been a major factor in explaining rural inequality, it has become less important. Capital input and farming structure are among the most important determinants of income inequality across households. Land holding is an equalizing factor but its equalizing impact is negligible. In contrast, non-farm activity, a result of 
the development of Township and Village Enterprises, and education attainment are among the driving forces behind rural inequality. As returns to education continue to favor the skilled, it will become an even more important factor in driving regional inequality (Wan, 2004). These sources of income divergence indicate that China is rapidly industrializing, like earlier developers, where education and non-farm activity are increasingly important and driving a wedge between the agrarian and non-farm households as well as between skilled and unskilled workers. ${ }^{4}$

\section{Methodology}

In this section, we discuss the evolutions of rural and urban household income in coastal and inland provinces using the Growth Incidence Curves (GIC). We then describe the shifts of income distributions and some functional assumptions which allow for a tractable quantification of the extent of poverty reduction from growth and distribution effects. Lastly, we present the income regression and the decomposition framework used for investigating the factors influencing household income growth.

\subsection{Growth Incidence Curve}

Growth Incidence Curve, developed by Ravallion and Chen (2001), describes the income growth rate of each segment of the population during the period of study. The GIC is a visual representation of the trend of income changes. GICs also allow one to examine the interactions among income growth, inequality and poverty reduction across segments of the population.

\footnotetext{
${ }^{4}$ See also Yang (1997).
} 
Mathematically, GIC indicates the growth rate in income between two points in time at each percentile of the distribution. More specifically, comparing two dates, $t-1$ and $t$, the growth rate in income of the $p^{\prime}$ th quintile is:

$$
g_{t}(p)=\frac{y_{t}(p)}{y_{t-1}(p)}-1
$$

Letting $p$ vary from zero to one, $g_{t}(p)$ traces out the GIC. For example, at the $50^{\text {th }}$ percentile, the figure gives the growth rate of the median income. If there is no change in inequality, $g_{t}(p)$ equals the average growth rate in mean income for all $p$. If $g_{t}(p)$ is a decreasing (increasing) function for all $p$ then inequality falls (rises) over time for all inequality measures, satisfying the Pigou-Dalton transfer principle. If the GIC lies above zero everywhere, i.e. $g_{t}(p) \geq 0$ for all $p$, then there is first-order dominance of the distribution at date $t$ over $t-1$. If the GIC is above the zero axis at all points up to some percentile $p^{*}$, then poverty has fallen for all headcount indices up to $p^{*}$ (for all poverty lines up to the value that yields $p^{*}$ as the headcount index) and for all poverty measures within a broad class. If the GIC switches sign then one cannot in general infer whether higher-order dominance holds by looking at the GIC alone.

\subsection{Poverty-Growth-Inequality arithmetic}

The Poverty-Growth-Inequality Triangle proposed by Bourguignon (2005) allows a tractable way to quantify the extent of poverty reduction into growth and distribution effects. The tractability of the decomposition hinges on the assumption that income is distributed according to a logarithmic normal distribution. Because the lognormal distribution is adequately defined by a variance and a 
mean, one can transform the initial income distribution into a hypothetical distribution based on the observed mean in the latter period, holding fixed the variance or into a final hypothetical distribution based on the new variance, but holding the mean unchanged. Figure 1 illustrates this decomposition. The poverty headcount is simply the area under the density curve to the left of the poverty line. Growth effects stand for the effects of a proportional change in all incomes that leaves the distribution of relative income unchanged while distribution effects denote the effects of a change in the distribution of relative incomes which is independent of the mean (Datt and Ravallion, 1992)..$^{5}$

\section{(Figure 1)}

Assuming every individual has the same increase of income that equals to the mean income growth of the entire population. This hypothetical distribution would have the same distribution as the initial one and the same mean value as the final one. It can thus be presented as the horizontal translation of the initial density curve to curve (I) in Figure 1, which stands for the pure "growth effect" with no change taking place in the distribution of relative incomes. The "distributional effect", which corresponds to the change in the distribution of "relative" income, is hence captured by the difference between this hypothetical intermediate distribution and the final one. In Figure 1, moving from curve (I) to the new distribution curve that occurs at constant mean income corresponds to the "distributional" effect. There could be some path dependence in this decomposition. The results may be slightly different between a "first horizontal then vertical"

\footnotetext{
${ }^{5}$ See also Bourguignon (2003), Dollar and Kraay (2002), Fields (2001), Kakwani (1993) and Ravallion (2001).
} 
translation and a "first vertical then horizontal" translation. We presume the difference is sufficiently small for our purpose of analysis.

\subsection{The effect of structural transformation on income changes}

Lastly, we will use a modified Mincerian type equation to specify our household income equation which will be the basis for a Blinder-Oaxaca type decomposition (Blinder, 1973; Oaxaca, 1973; Smith and Welch, 1989; The World Bank, 2007). Attributes influencing household income will be included in the household income equation. They consist of human capital variables of the household head (e.g., age, education, and occupation) and other adult household members; household characteristics (e.g., place of residence, dependency ratio, and amount of farm land for only rural households).

Mathematically, starting from two household income equations for each household:

$$
\begin{array}{ll}
\log y_{i}=\sum_{k=1}^{K} \beta_{k}^{89} x_{k, i}+\mu_{i}^{89} & \text { for } 1989 \\
\log y_{i}=\sum_{l=1}^{K} \beta_{k}^{04} x_{k, i}+\mu_{i}^{04} & \text { for } 2004
\end{array}
$$

where $y_{i}$ represents the real per capita income of household $i$; and $X_{i}=\left.\left\{x_{k, i}\right\}\right|_{k=1} ^{K}$ are the independent variables, we estimate:

$$
\begin{array}{ll}
\log \hat{y}_{i}=\hat{\beta}^{89} X_{i} & \text { for } 1989 \\
\log \hat{y}_{i}=\hat{\beta}^{04} X_{i} & \text { for } 2004
\end{array}
$$


We can decompose the influence of various attributes into (i) main (characteristic or endowment) effects that occur because of changes in household characteristics and (ii) year (price or coefficient) effects which are due to changes in return to the specific characteristics. This decomposition allows one to assess the sources of income disparity.

In other words, the per capita household income growth during the period 1989-2004 can be decomposed as follows:

$$
\log \tilde{y}_{04}-\log \tilde{y}_{89}=\hat{\beta}^{89}\left(\bar{X}_{04}-\bar{X}_{89}\right)+\left(\hat{\beta}^{04}-\hat{\beta}^{89}\right) \bar{X}_{04}
$$

where $\tilde{y}_{89}$ and $\tilde{y}_{04}$ are geometric mean income in 1989 and 2004 , respectively. $\hat{\beta}^{89}\left(\bar{X}_{04}-\bar{X}_{89}\right)$ denotes the main effect of the independent variables, that is, endowment or characteristic effects, and $\left(\hat{\beta}^{04}-\hat{\beta}^{89}\right) \bar{X}_{04}$ the year effect, which represents changes in returns to specific characteristics. ${ }^{6}$ For instance, the main effect of education signifies the rising schooling attainment of the population, and that of industry represents a structural transformation or the changing industry composition. The year effect of education signifies the changes in returns to education, and that of occupation represents the changes in relative industry premiums.

Note that the Blinder-Oaxaca decomposition of wage differentials is not invariant to the choice of reference group when a set of dummy variables is used. See, for example, Oaxaca and Ransom (1999). In our context, the different choices of reference groups do not affect our findings. Our main variables of interest are a continuous variable of schooling attainment and a binary variable of location. Nevertheless, for ease of interpretation and consistency, we use "normalized" regressions developed in Yun (2005) to identify the constant and estimates of categorical dummy

\footnotetext{
${ }^{6}$ Also see Neumark (1988).
} 
variables to address the identification problem so that the wage differential is no longer subject to the choice of reference group.

\section{Results}

The results are presented in three parts. The first part analyzes the evolution of rural and urban household per capita income in coastal and inland provinces between 1989 and 2004. The second part discusses the extent of poverty reduction. And, the third part investigates the determinants of income and their relative contributions to income growth.

\subsection{Trends in income growth and inequality}

Between 1989 and 2004, income in coastal provinces more than tripled whilst that in inland provinces, doubled. In 1989, average per capita household income in inland provinces was 982 yuans, making up 85 percent of that in coastal provinces of 1149 yuans. By 2004, average income in coastal provinces had grown so rapidly that the mean per capita household income in inland provinces at 2338 yuans was barely two-third of the coastal average of 3537 yuans (Table 1). During this 15-year period, income growth has also been more rapid in urban areas of both coastal and inland provinces. Average household per capita income multiplied 2.5 times in rural areas and rose 3 times in urban areas. Correspondingly, rural-urban income gap also increased. Mean household per capita income in urban areas was 40 percent higher than that in rural areas in 1989, but rose to and 60 percent by 2004 .

(Table 1) 
The rapid growth in per capita household income also accompanies a rapid rise in within-area inequality. Total inequality rose more rapidly in inland provinces (Table 2). The Gini coefficients in urban areas almost doubled, with inland urban areas experiencing a far greater gap than the coastal urban areas. Likewise, the rural-urban gap in inland provinces was also wider than that in coastal provinces. In 2004, the urban-rural income gap as a percent of the rural average was 0.46 among coastal provinces, and 0.73 in inland provinces. Rural household per capita income tripled in the coast while doubled in the inland. This observed trend of greater inequality in slower growing inland provinces of lower income is consistent with the stylized Kuznets curve. This trend is also a direct consequence of the government's concerted effort to initially concentrate scarce resources to promote coastal areas' growth to ensure that it will lead China into world markets. The famous Kuznets inverted U-curve (Kaldor, 1956; 1957; Kuznets, 1955) suggests that overall inequalities first rise in the early phases of a country's development, and then level off in the advanced stage of development as a greater amount of resources can now be more widely shared. ${ }^{7}$ The coastal areas of China, at a higher level of per capita GDP after decades of rapid growth, are witnessing a smaller urban-rural income gap.

\section{(Table 2)}

The simultaneous increase in income and inequality, presented in Tables 1 and 2, can be visually summarized by the Kernel density distributions in Figure 2. For the coastal provinces, both the urban and rural distributions have shifted rightward, indicating a rise in income. The urban

\footnotetext{
${ }^{7}$ The turning point may depend on, among other factors, population size and openness of economy. See Chen (2007).
} 
distribution has also become significantly more unequal. For the inland provinces, the shifts in the distributions are qualitatively similar: rural and urban areas experienced positive income growth while urban inequality grew substantially.

\section{(Figure 2)}

The kernel density distributions only provide broad summary statistics. To understand the relative income gains of various segments of the distributions during this period, we present in Figure 3 two sets of growth incidence curves. The top panel consists of rural and urban areas of coastal provinces, and the bottom panel, the inland provinces. In coastal provinces, a U-shaped growth incidence curve for rural areas suggests that the poorer segments of rural population have experienced among the highest growth. Their income, growing more rapidly than the richer segments, has enabled a convergence. This was reflected in the rapid poverty reduction in coastal rural areas and a narrower rural-urban income gap in coastal provinces.

\section{(Figure 3)}

In inland provinces, however, the growth performance has been less progressive. While the better-off segment of the rural population experienced a higher income growth than the poorer segments in rural areas, the growth differential was relatively smaller than that in the urban areas. In urban inland areas, income grew significantly more rapidly among the richer groups of the urban population. Thus, a divergence of income within urban areas and between rural and urban areas resulted during this period in inland provinces. 
The rapid income growth of the poorest in rural coastal provinces could be attributed to the prosperity of Township and Village Enterprises (TVEs) and other non-farm activities because of their proximity to economic centers - Shanghai for Jiangsu, Bohai Economic Zone for Shandong and Liaoning. Internal migration and remittance also play a role. In contrast, a culprit for slow growth in the bottom hierarchy of the urban population could be attributed to the widespread retrenchment of State Owned Enterprises (SOE). Until the SOE reforms in the 1990s, a large part of urban workers belonged to SOEs or collectively owned enterprises. The reforms gave enterprises flexibility in hiring and firing workers and in determining workers' pay, and encouraged financially unviable enterprises to merge or shut down. Workers with higher ability or skills could more easily find gainful employment outside of the public enterprises. However, a large number of urban workers, laid-off from SOEs and collective-owned enterprises, were unskilled. Furthermore, the imperfect tax system has not been effective in taxing and redistributing.

\subsection{The impacts of growth and inequality on poverty reduction}

Consistent with the most rapid growth of income in coastal areas, poverty reduction was also most significant there. By 2004, poverty incidence was 9 percent in coastal areas compared to 22 percent in inland provinces. Subject to the 1.5 dollars-a-day poverty line, ${ }^{8}$ rural poverty headcount in coastal areas in 2004 (at 11 percent) was less than one third of that in 1989 (at 34 percent). Likewise, poverty incidence in coastal urban areas fell from 16 percent to 6 percent

\footnotetext{
${ }^{8}$ Adjusted by rural and urban CPI at the provincial level, we translate 1.5 dollars-a-day into 830 yuans for urban areas and 639 yuans for rural areas, per capita per year 1989 price.
} 
(Table 3). In inland provinces, poverty reduction in rural areas, almost halving from 47 percent to 24 percent, was more rapid than in urban areas, falling from 27 percent in 1989 to 18 percent in 2004. ${ }^{9}$

\section{(Table 3)}

The significant poverty reduction witnessed in the leading coastal areas of rapidly economic growth during this period has led to an inland-coastal divergence. However, this divergence is a positive consequence of a country's early phase of growth and development. Leading areas were pulling people out of poverty at a faster pace than lagging areas with relatively slower, albeit positive, growth. Thus, overall welfare has improved in all eight provinces with poverty incidence being halved during 1989-2004. To estimate the extent of poverty reduction as a result of rising income and inequality, we conduct a decomposition of the shifts in the distributions.

For tractability, we follow Bourguignon's analysis and assume a log-normal distribution of income (Bourguignon, 2002). The decomposition has two steps. First, to estimate the growth effect on poverty reduction, we shift the distribution as if everyone experiences an income growth similar to the increase of the mean. Next, to estimate the rising inequality's effect on poverty reduction, we shift the distribution to reflect its new variance. Figure 4 shows the shifting density distributions of household per capita income for inland and coastal areas, separated into rural and

\footnotetext{
${ }^{9}$ Rural poverty rate can be overestimated relative to urban poverty rate based on single poverty line as the difference in cost-of-living between rural areas and urban areas has not been taken into account (Ravallion and Chen, 2007). The trends of poverty reduction for the entire sample and for coastal and inland provinces stay unchanged when we adjust rural income taking income cost-of-living difference. Results are available upon request.
} 
urban areas, respectively. Simulated poverty headcount, measured by the percentage of population with a household per capita income below a certain level, is captured by the area under the density curve to the left of the poverty line.

\section{(Figure 4)}

The results of Figure 4 are summarized in Table 4. As long as the assumption of log-normality holds for the income distributions, this decomposition exercise provides some glimpses into the relative importance of distributional and growth effects on poverty reduction. Over the period of 1989-2004, poverty reduction has primarily been a result of rapid income growth. The (hypothetically) dampening effect of poverty increasing as a result of worsening distribution has been relatively small, especially in the presence of significant growth effect on poverty reduction. As discussed earlier, the divergence in the case of China was due primarily to the leading coastal areas pulling ahead at a more rapid pace than the lagging inland areas of slower but positive growth. Therefore, poverty reduction, albeit not at a uniform rate across places, has been universal.

\section{(Table 4)}

\subsection{Sources of income growth}

Having examined the trends of household income, inequality and poverty, we now investigate the determinants of household income specified in equations (1) and (2), that is, separately for the years 1989 and 2004. Modifying a standard Mincerian human capital equation, we include as 
explanatory variables the age, schooling, occupation, and employer of the head of household; the number of skilled workers in the household; the number of household members working in nonagricultural activity; and the household's location (coastal or inland) variable. This set of variables for the urban household income equation is enlarged for the sample of rural households to also include the amount of per capita farm land and participation of off-farm activities. Many researches show that non-farm activity plays an increasingly important role in rural income (FAO, 1998). Skilled workers here refer to white-collar and technical occupations such as professional/technical personnel, administrator, factory manager, engineering, government official, and office staff. Unskilled workers consist of blue-collar occupations. ${ }^{10}$

Because of the nature of this particular dataset which consists of predominantly panel data of households, we anticipate much less variation between years in these household characteristics than two random dataset of cross-sections. Despite this shortcoming, the results presented in Table 5 suggest a compelling story of economic forces at work after the effects of reform set in. Most importantly, returns to schooling and to high-skilled occupations have increased several folds during this 15-year period. During this time, the premium to coastal location also multiplied. These results hold in rural as well as urban areas. The economic reform unleashed market forces that promote efficient reallocation of resources. Workers can self-select into jobs based on their own comparative advantages that better value their attributes. The higher returns to skills in China reflect the increasing demand for skills from globalization and technology, as in other open economies.

\footnotetext{
${ }^{10}$ According to CHNS's sampling design, cities include suburban neighborhoods and county seat. Thus there is a small part of households who live on farm activities in urban areas.
} 


\section{(Table 5)}

The other household specific variables such as the number of skilled workers in the household; the number of members engaging in non-agricultural activity; land holding, and participation in off-farm activity have their expected signs. The shortage of land is a persisting problem in rural China. The average land area was small (about 0.30 hectare) and virtually unchanged between 1989 and 2004. Under the current land regime, land cannot be freely exchanged between households. This limits the concentration of land and hinders agricultural scale economy. Thus, traditional farming still dominates China's countryside. Correspondingly, the returns to land holding have remained unchanged during this 15-year period. Given the high demographic pressure in countryside and the limited quantity of arable land, non-agrarian activities plays an important role in absorbing surplus agricultural labor. By 2004, the returns to agrarian off-farm activity (e.g., livestock, fishery, horticulture etc) were not significantly different from the unemployed. But, in contrast, households working on small handicraft or commercial business have significantly higher income, and jobs in the secondary and tertiary sectors or skilled workers fetched large premium by 2004.

Table 6 presents the results of decomposition. Over two-third of income growth can be explained by human-capital related variables and their returns. For instance, in urban areas, the rising returns for schooling make up half of the income growth. And, self-selection into skilled jobs or working in a non-agrarian entity are also important. The location factor - being in a coastal province - is also critical, contributing to 10 percent of income growth. This reflects the benefits, among others, of proximity to world markets; agglomeration economies; higher demand; and 
better job matching. Among rural households, the location effect of being in a coastal province is even more important than in urban areas. Being in a coastal rural area enhances income growth by as much as 20 percent, compared to being in an interior rural area. Rural areas in a dynamic region are likely to be more integrated with their urban areas, and hence, sharing in on the prosperity.

\section{(Table 6)}

Besides the location effect, human capital related factors are also more important in rural than in urban areas. The combined effects of higher returns to schooling (contributing a quarter of the income growth); an increase proportion of skilled jobs or non-agrarian activities (constituting 20 percent); and the higher returns to modern sector employment all result in over three-quarter of rural income growth. These results suggest that there has been a structural transformation during this period with a significant shift of workers from agrarian activity into secondary and tertiary sectors. And, a remuneration wedge or income gap between non-agrarian and agricultural activity has also widened.

It's important to note that the negative contribution of the main effect from skilled jobs or engagement in non-agrarian entity to income growth stems from the rise in unemployment and out of labor force during this period. Employment rate fell from 87.7 percent to 59.8 percent during this period, reflecting retrenchment and early retirement from SOE reform. Furthermore, there is a widening income gap between the employed and the unemployed. In the 1980s, explicit urban unemployment did not exist and wage level was generally low. The difference between employment wage and retirement pension was small. However, since the 1990s, wage income 
and bonus income have increased for the employed, while retirement pension stayed almost unchanged. The coverage of retirement pension even decreased due to the closure of bankrupt enterprises (see also Fang et al., 2002; Meng et al., 2007). In short, the sharp rise in out-ofemployment (including the unemployed and retired) between 1989 and 2004 and their income gap are contributing to widening urban income inequality.

\section{Discussion and Conclusion}

The increase in inequality in 1989-2004 is largely a result of the differential opportunities and remuneration between the skilled and unskilled. During the transition from planned to market economy, institutional reforms failed to keep pace. Rent-seeking, unclear property rights in SOEs, and imperfect tax system have benefited some at the expense of the others. In urban areas, retrenchment from SOEs and collective-owned-enterprises, and reduction in real income of the retired also contributed to widening income gap, especially in urban areas. In rural areas, limited amount of land and traditional production lead to low agricultural productivity. It will be crucial to develop rural non-farm sectors to absorb redundant agricultural labor and to raise returns to grain-cropping (Wan and Zhou, 2005). Migration to urban areas to seek more gainful employment has also been another avenue towards prosperity for the rural masses.

One key finding is that education plays an increasingly important role in household income determination for both urban and rural areas. Income gaps have increased between households with greater human capital endowment and those with less. This corroborates the findings of many researches that returns to education increased significantly as the reforms deepened in China (Wan, 2004). Knight and Song (1999) argue that in China, the place of a person's birth is 
one of the most important determinants of that person's adult skill level. As resource constraints differentially affect access to education of individuals in different parts of China, especially in rural areas and in the poor inland provinces, inequality in opportunity may lead to inequality in income in the long-run and worsen regional disparity (Heckman, 2005). In pre-reform era, people with different education level earned similar income. Since economic reforms, return to education has become more important. According to the study of Zhang et al. (2005), the wage returns to one additional year of schooling almost tripled between 1988 and 2003, from 4 percent to 11 percent. As well-educated people are more likely to live in urban areas with higher income, the increase in returns to education initially leads to an increase in overall inequality. However, as Dollar (2007) argues, the trend will be an inverted U-shape - if equality of opportunity or universal access to education is attained, income disparity will fall as a greater share of the population will become educated.

A decomposition analysis based on household income determination shows that the largest proportion of changes in total income can be attributed to the increase in returns to education. As economic reforms deepen, labor market works more efficiently by balancing demand and supply of skills. Scarce skilled labor is commanding higher premium. Such efficiency gain is one important force that drives rapid economic growth, while at the same time contributes to rising inequality. Like in many developing countries, education is one of the key paths out of poverty in China (Dollar, 2007). Among those with nine years or more of education, poverty rate is only 2 percent compared to a 10 percent national average in China. Under the uniquely decentralized fiscal system, funding education is primarily responsibilities of local governments. As poor localities are less able to fund these services and poor households are less able to afford high private cost of basic education, there has been an increase in inequality of educational outcomes. 
For example, in 1998, per pupil expenditure in Beijing was 12 times that in Guizhou; and the difference jumped to 15 times in 2001. Inequality of access to education is an important source of inequality in China across people contemporaneously and across generations (Heckman, 2003; 2005).

Before 1978, China was a poor egalitarian society. The reforms have unleashed market forces, and improved economic efficiency. As a result, disparity in income widened as the economy developed. Using CHNS data, we examined the changes in income inequality and poverty during 1989-2004 and the impacts of structural transformation on income growth. We find that everyone has benefited from economic growth and poverty has fallen. However, some segment of the population benefited more than the others. Thus, Inequality in per capita household income widened, especially between coastal urban and inland urban residents.

Inequality of income can be inevitable at a certain stage of development. However, inequality of opportunity will undermine long-term prospect of development. Human capital is an asset that ultimately conditions the wealth of a nation. Improving access to basic education, especially in poor rural areas, is hence important for enhancing growth and fighting poverty. 


\section{References}

Bishop, J., Luo F., Pan X., 2006. Economic transition and subjective poverty in urban China. Review of Income and Wealth 52(4), 625--641.

Blinder, A. S., 1973. Wage Discrimination: Reduced Form and Structural Estimates. The Journal of Human Resources 8(4), 436--455.

Bourguignon, F., 2002. The Distributional Effects of Growth: Case Study vs. Cross-country Regressions. Paper presented at CEPAL, Santiago de Chile, in August 2001. Mimeographed, revised version.

Bourguignon, F., 2003. The Growth Elasticity of Poverty Reduction: Explaining Heterogeneity across Countries and Time Periods, in: Eicher, T., Turnovsky, S. (Eds.), Inequality and growth: Theory and Policy Implications. The MIT Press, Cambridge, pp. 3--26.

Bourguignon, F., 2005. Poverty-growth-inequality triangle: With some reflections on Egypt. Distinguished Lecture Series, No. 22. Egyptian Center for Economic Studies, Cairo, Egypt.

Chaudhuri, S., Ravallion, M., 2006. Partially awakened giants: uneven growth in China and India. Policy Research Working Paper, No. 4069. The World Bank, Washington D.C.

Chen, S., Ravallion, M., 2007. Absolute poverty measures for the developing world, 1981-2004. Policy Research Working Paper, No. 4211. The World Bank, Washington D.C.

Chen, S., Ravallion, M., 2008. The developing world is poorer than we thought, but no less successful in the fight against poverty, Policy Research Working Paper, No. 4703. The World Bank, Washington D.C. 
Chen, S., Wang, Y., 2001. China's growth and poverty reduction: recent trends between 1990 and 1999. Paper presented at a WBI-PIDS Seminar on Strengthening Poverty Data Collection and Analysis held in Manila, Philippines, April 30-May 4, 2001.

Chen, Z, Eastwood, D.B., Yen, S.T., 2007. A decade's story of childhood malnutrition inequality in China: Where do you live does matter. China Economic Review 18(2), 139--154.

Chen, Z., 2007. Development and inequality: an endogenous switching regression approach, Economics Letters 2007 96(2), 269--274.

Chotikapanich, D., Rao, D.S.P., Tang, K.K., 2007. Estimating income inequality in China using grouped data and the generalized beta distribution. Review of Income and Wealth 53(1), 127-147.

Datt, G., Ravallion, M., 1992. Growth and Redistribution Components of Changes in Poverty Measures: a Decomposition with Application to Brazil and India in the 1980s. Journal of Development Economics 38(2), 275-295.

Dollar, D., 2007. Poverty, inequality and social disparities during China's economic reform. Policy Research Working Paper, No. 4253. The World Bank, Washington D.C.

Dollar, D., Kraay, A., 2002. Growth Is Good for the Poor. Journal of Economic Growth 7(3), $195--225$.

Fan, S., Zhang, L., Zhang, X., 2002. Growth, Inequality and Poverty in Rural China: The Role of Public Investments. International Food Policy Research Institute, Research Report 125.

Fang, C., Zhang, X., Fan, S., 2002. Emergence of urban poverty and inequality in China: evidence from household survey. China Economic Review 13(4), 430--443.

FAO, 1998. The state of food and agriculture 1998. FAO, Rome.

Fields, G., 2001. Distribution and Development: a New Look at the Developing World. The MIT Press, Cambridge. 
Gustafsson, B., Li, S., 2002. Income inequality within and across counties in rural China 1988 and 1995. Journal of Development Economics 69(1), 179-204.

Heckman, J.J., 2003. Selection Bias, Comparative Advantage and Heterogeneous Returns to Education: Evidence from China in 2000. NBER Working Paper 9877.

Heckman, J.J., 2005. China‘s human capital investment. China Economic Review 16(1), 50--70.

Heerink, N., Kuiper, M., Shi, X., 2006. China's New Rural Income Support Policy: Impacts on Grain Production and Rural Income Inequality. China \& World Economy 14(6), 58--69.

Kakwani, N., 1993. Poverty and Economic Growth with Application to Côte d'Ivoire. Review of Income and Wealth 39(2), 121-139.

Kaldor, N., 1956. Alternative Theories of Distribution. Review of Economic Studies 23(2), 83-100.

Kaldor, N., 1957. A Model of Economic Growth. Economic Journal 67(268), 591--624.

Kanbur, R., Zhang, X., 1999. Which regional inequality? The evolution of rural-urban and inland-coastal inequality in China, 1983-1995. Journal of Comparative Economic 27(4), 686-701.

Khan, A.R., Riskin, C., 2001. Inequality and poverty in China in the age of globalization. Oxford University Press, New York.

Knight, J., Song, L., 1999. The Rural-Urban Divide : Economic Disparities and Interactions in China. Oxford University Press, Oxford.

Kuznets, S., 1955. Economic growth and income inequality. American Economic Review 45(1), 1-28.

Li, H., Zhu, Y., 2006. Income, income inequality, and health: Evidence from China. Journal of Comparative Economics 34(4), 668--693. 
Lu, D. 2002. Rural-urban income disparity: impact of growth, allocative efficiency, and local growth welfare. China Economic Review 13(4), 419--429.

Meng, X., Gregory, R., Wan, G., 2007. Urban poverty in China and its contributing factors, 1986-2000. Review of Income and Wealth 53(1), 167--189.

Meng, X., Gregory, R., Wang, Y., 2005. Poverty, inequality, and growth in urban China 19862000. Journal of Comparative Economics 33(4), 710--729.

Neumark, D., 1988. Employers' Discriminatory Behavior and the Estimation of Wage Discrimination. The Journal of Human Resources 23(3), 279--295.

Oaxaca, R.L., 1973. Male-Female Wage Differentials in Urban Labor Markets. International Economic Review 14(3), 693--709.

Oaxaca, R.L., Ransom, M.R., 1999. Identification in detailed wage decompositions. The Review of Economics and Statistics 81(1), 154--157.

Ravallion, M., 2001. Growth, Inequality, and Poverty: Looking Beyond Averages, Working Paper No. 2558. The World Bank, Washington D.C.

Ravallion, M., Chen, S., 2001. Measuring Pro-Poor Growth. Policy Research Working Paper, No. 2666. The World Bank, Washington D.C.

Ravallion, M., Chen, S., 2007. China's (Uneven) Progress Against Poverty. Journal of Development Economics 82(1), 1--42.

Renard, M-F., 2002. A pessimistic view on the impact of regional inequalities. China Economic Review 13(4), 341--344.

Sicular, T., Yue, X., Gustafsson, B., Shi, L., 2007. The Urban-Rural Income Gap and Inequality in China. Review of Income and Wealth 53(1), 95--128.

Smith, J., Welch, F.R., 1989. Black Economic Progress After Myrdal. Journal of Economic Literature 27(2), 529--564. 
The World Bank, 2007. Sharing Growth: Equity and Development in Cambodia. The World Bank, Washington D.C.

Tsui, K.Y., 1991. China's Regional Inequality, 1952-85. Journal of Comparative Economics $15(1), 1--21$.

Tsui, K.Y., 2007. Forces shaping China's interprovincial inequality Review of Income and Wealth 53(1), 60--92.

Wade, R.H., 2004. Is Globalization Reducing Poverty and Inequality?. World Development 32(4), 567-589.

Wan, G., 2004. Accounting for income inequality in rural China a regression-based approach. Journal of Comparative Economics 32(2), 348-363.

Wan, G., 2007. Understanding regional poverty and inequality trends in China: methodological issues and empirical findings. Review of Income and Wealth 53(1), 25--59.

Wan, G., Lu, M., Chen, Z., 2006. The inequality-growth nexus in the short and long run: Empirical evidence from China. Journal of Comparative Economics 34(4), 654--667.

Wan, G., Lu, M., Chen, Z., 2007. Globalization and regional income inequality: empirical evidence from within China. Review of Income and Wealth 53(1), 35--59.

Wan, G., Zhou, Z., 2005. Income Inequality in Rural China: Regression-based Decomposition Using Household Data. Review of Development Economics 9(1), 107--120.

Wang, Q., Shi, G., Zheng, Y., 2002. Changes in income inequality and welfare under economic transition: evidence from urban China. Applied Economics Letters 2002-9, 989--991.

Wu, F., 2004. Urban poverty and marginalization under market transition: the case of Chinese cities. International Journal of Urban and Regional Research 28(2), 401--423.

Yang, D. T., 1997. Education in production: measuring labor quality and management. American Journal of Agricultural Economics 79(3), 764--772. 
Yu, L., Luo, R., Zhang, L., 2007. Decomposing income inequality and policy implications in rural China. China \& World Economy 15(2), 44--58.

Yun, M-S., 2005. A Simple Solution to the Identification Problem in Detailed Wage Decompositions, Economic Inquiry 43(4), 766--772.

Zhang, J., Zhao, Y., Parl, A., Song, X., 2005. Economic returns to schooling in urban China, 1988-2001. Journal of Comparative Economics 33, 730--752.

Zhang, Y., Wan, G., 2006. The impact of growth and inequality or rural poverty in China. Journal of Comparative Economics 34 (4), 694--712. 


\section{Figures and Tables}

Figure 1 - Decomposition of distribution shifts into growth and distributional effects

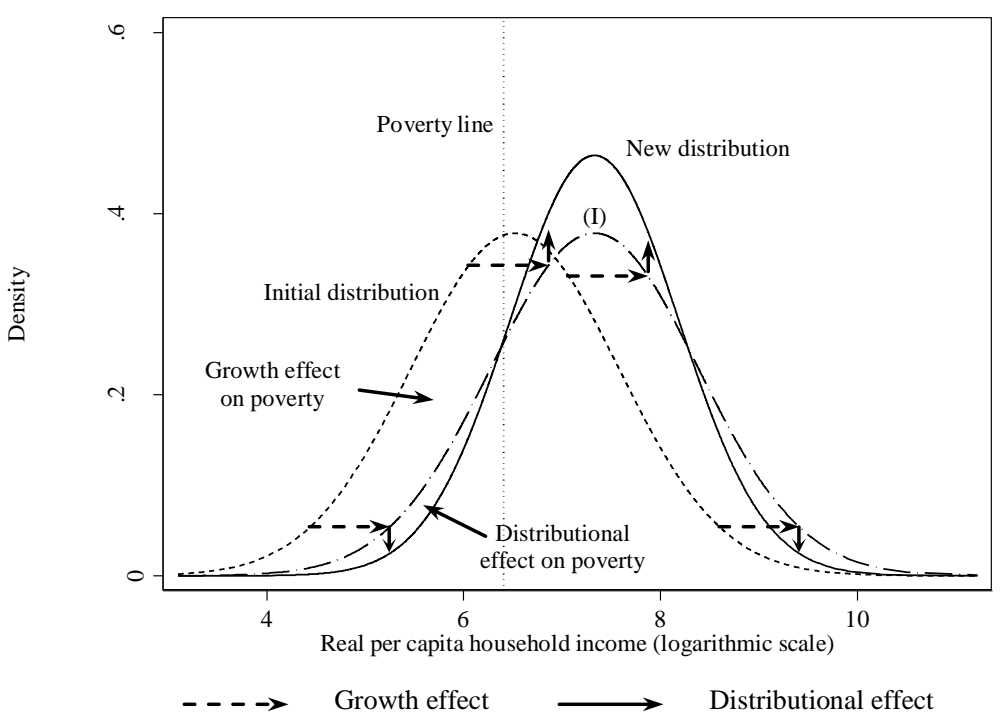

Source: Bourguignon (2005). 
Figure 2 - Kernel density of household per capita income, 1989 and 2004

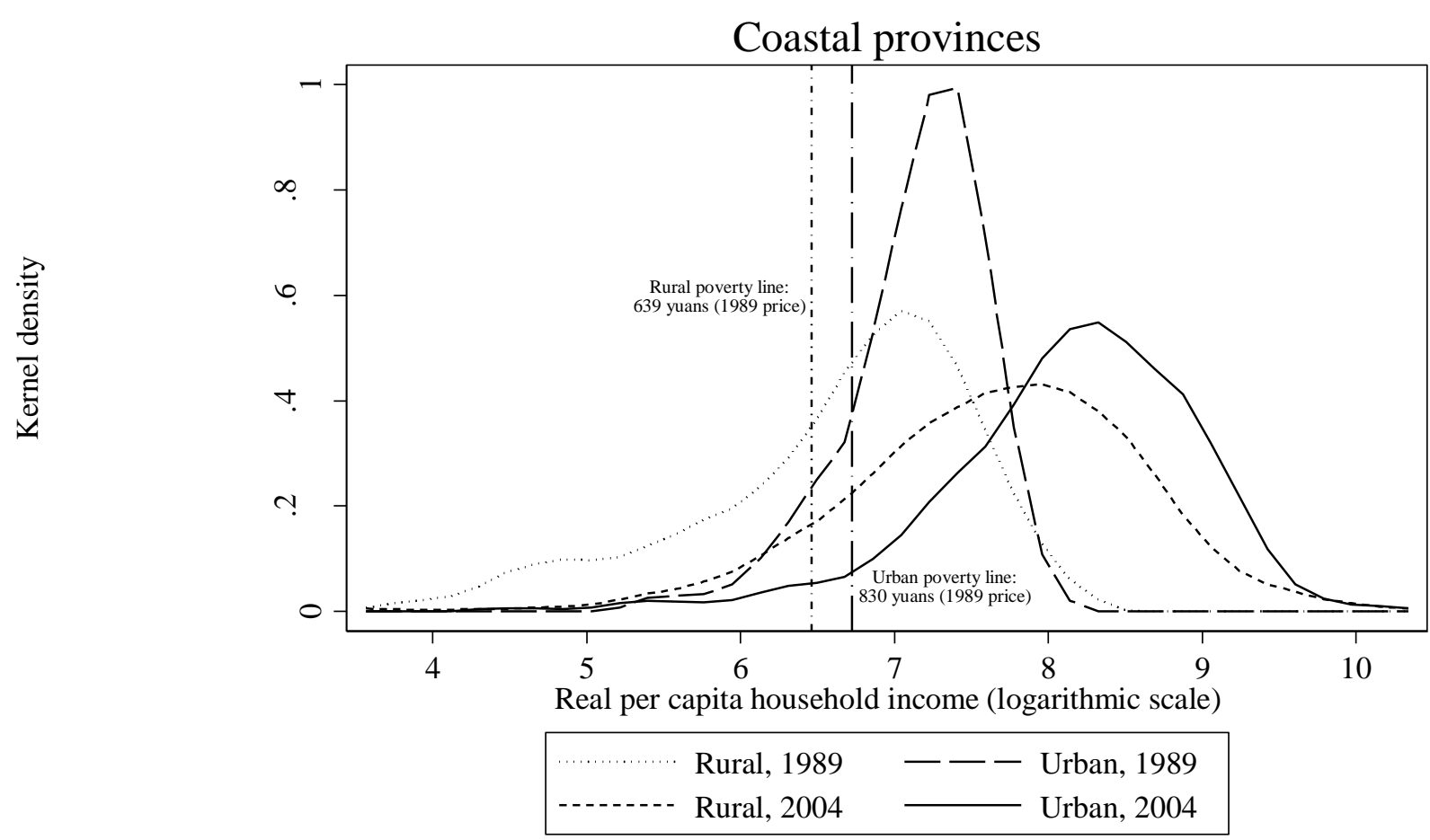

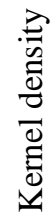

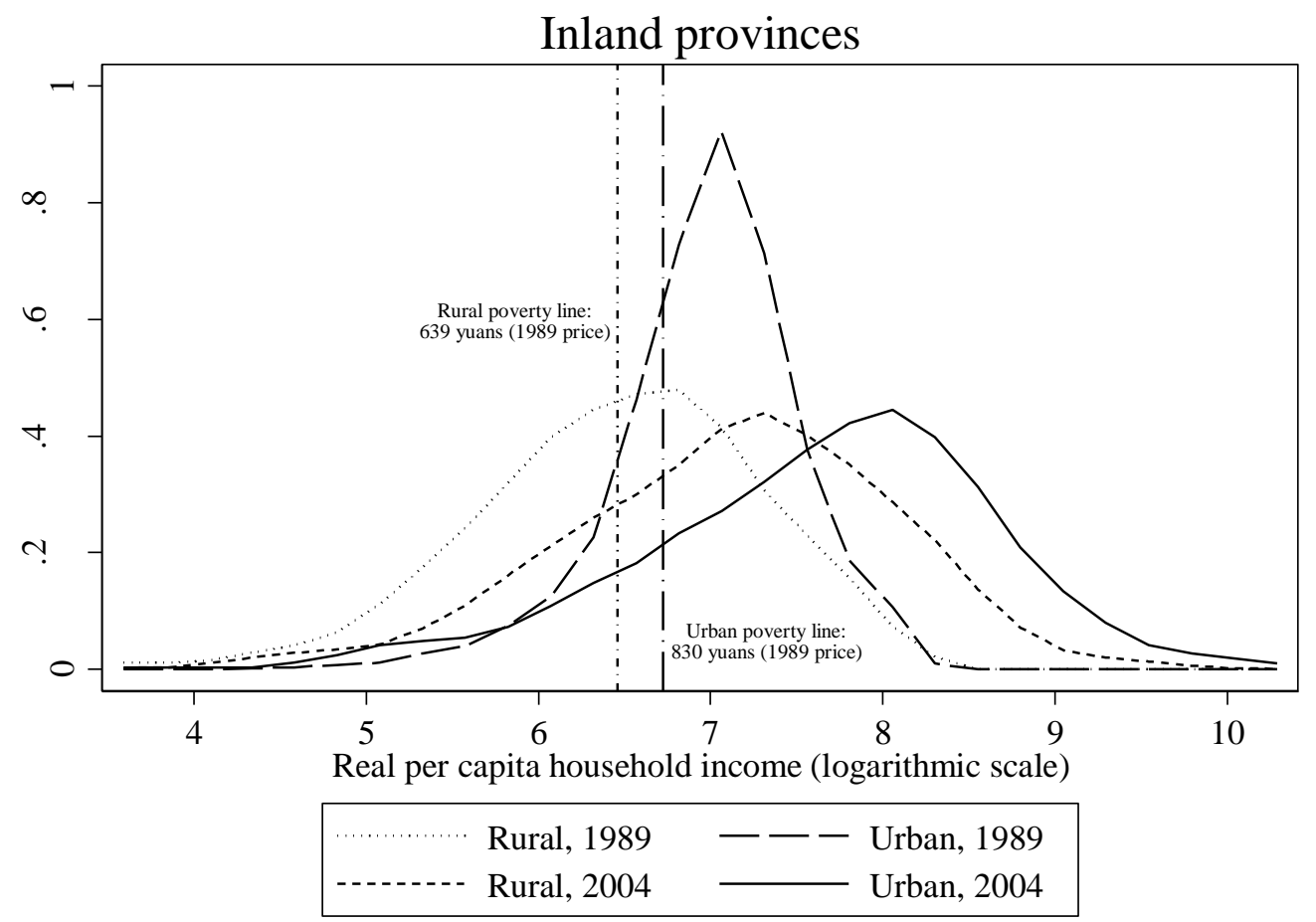


Figure 3 - Growth incidence curve, 1989-2004
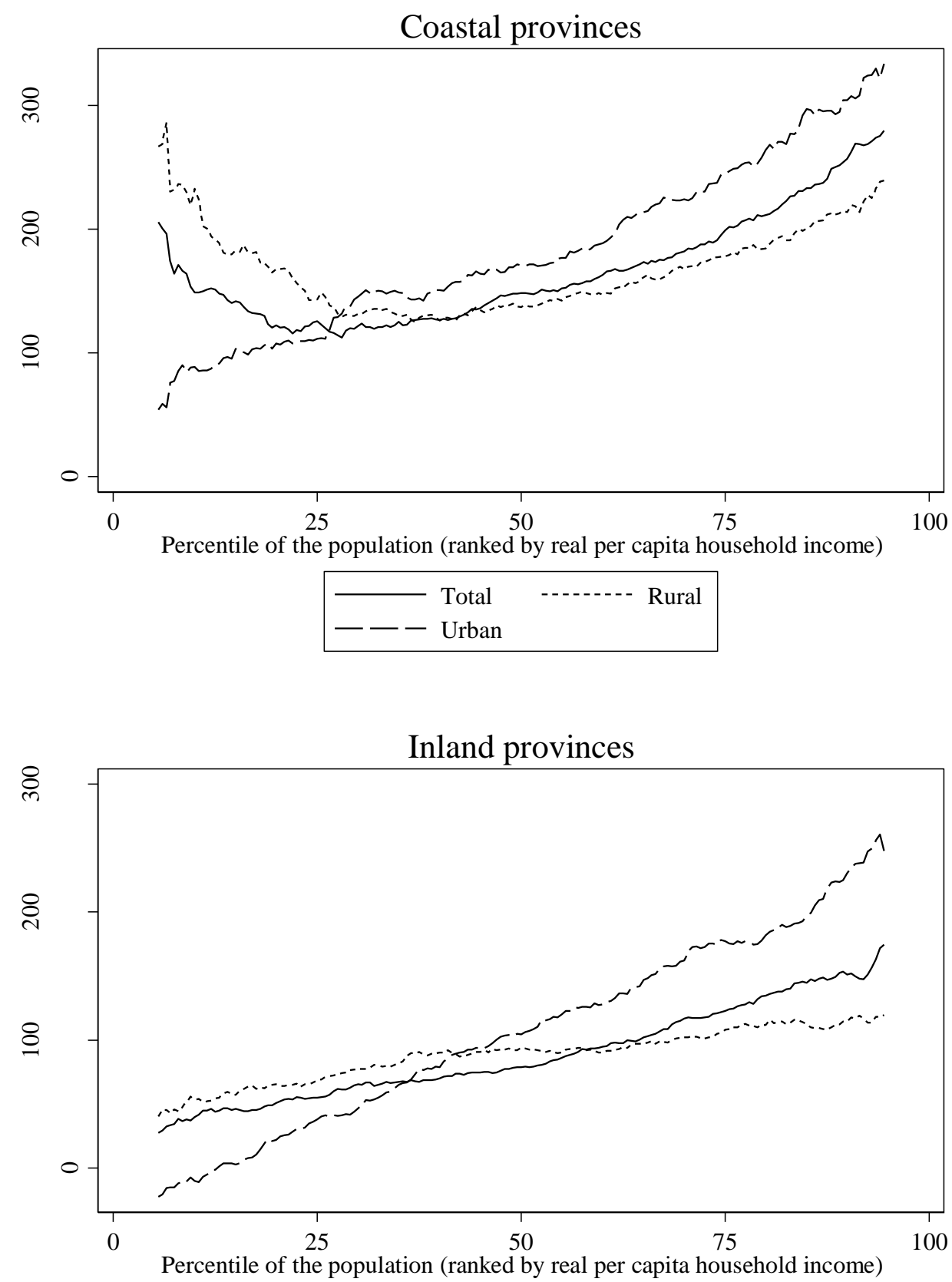

\begin{tabular}{llll}
\hline & Total \\
- & Urban & & \\
&
\end{tabular}


Figure 4 - Growth and distributional effects on poverty reduction. 1989-2004

\section{Coastal provinces}
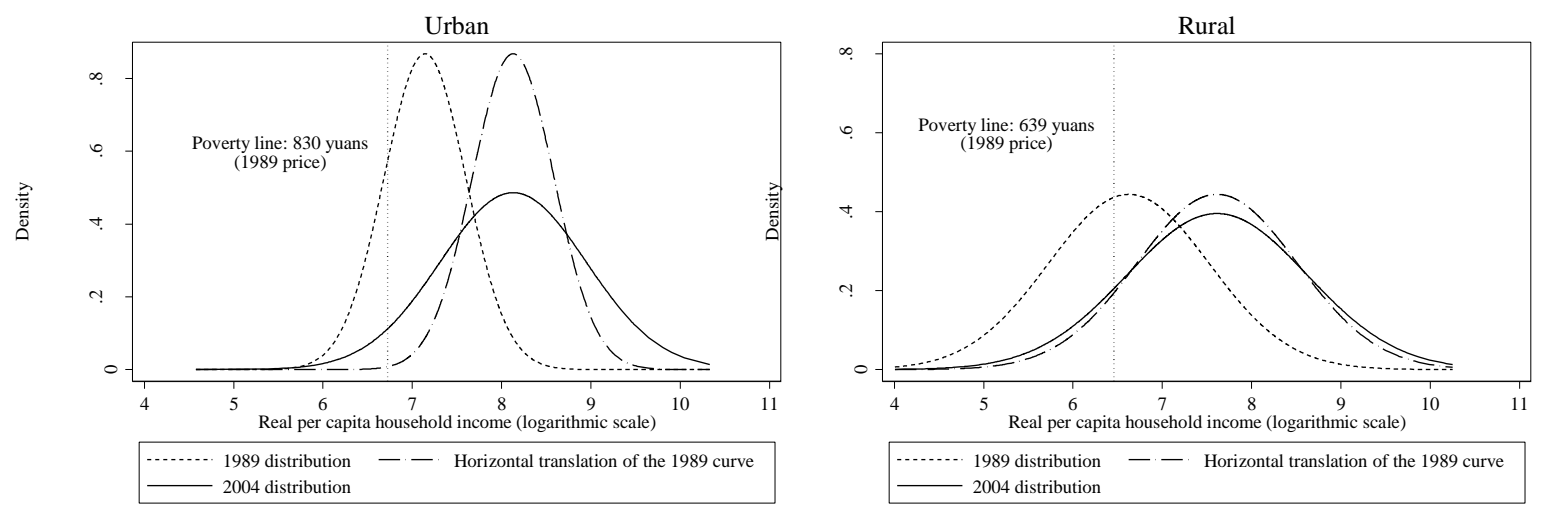

Inland provinces
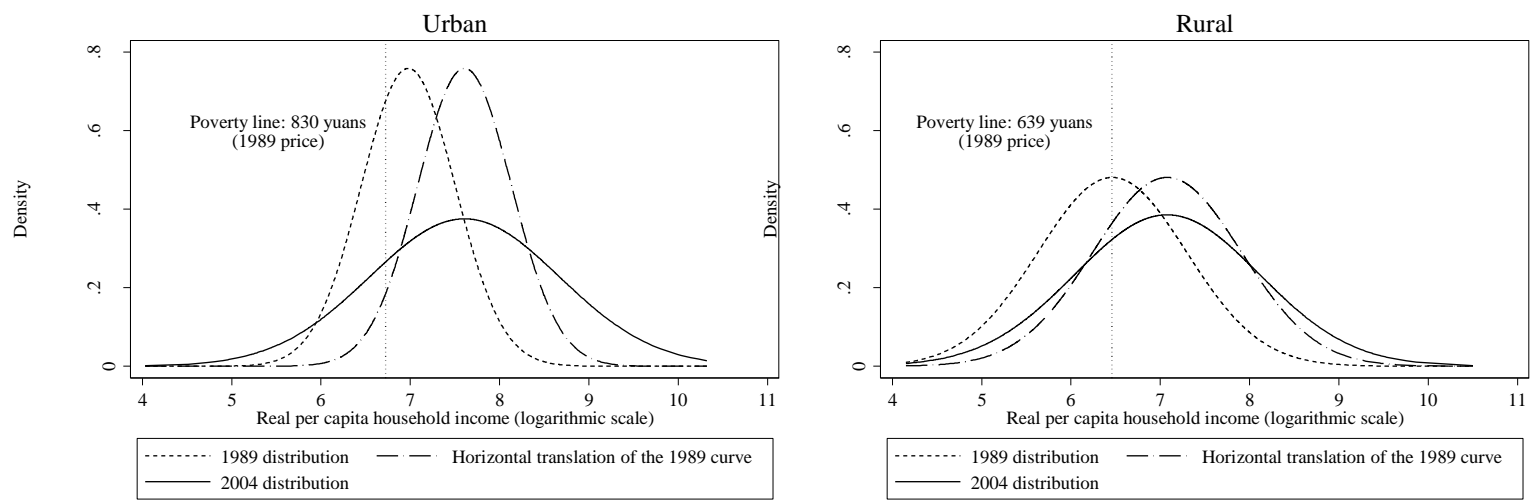
Table 1 - Household per capita income, 1989-2004

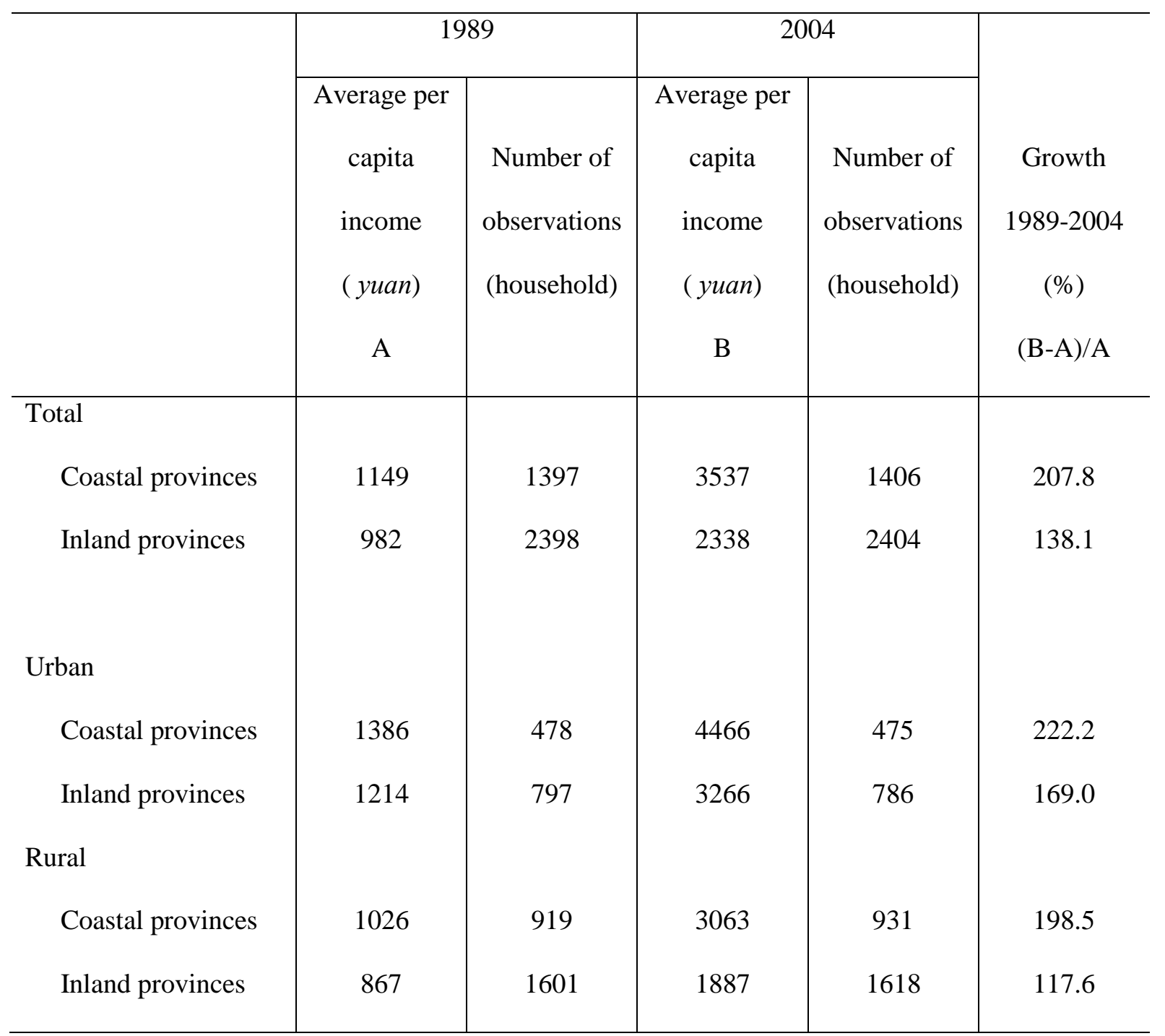

Household income in 2004 is adjusted to 1989 price using rural/urban Consumer Price Index (CPI) at the provincial level provided by China Statistical Yearbooks. 
Table 2 - Gini coefficients of household per capita income, 1989-2004

\begin{tabular}{l|c|c|c}
\hline & 1989 & 2004 & Change (\%) \\
& A & B & (B-A)/A \\
\hline Total & 0.327 & 0.436 & 33.3 \\
Coastal provinces & 0.365 & 0.505 & 38.4 \\
Inland provinces & & & \\
Urban & & & \\
Coastal provinces & 0.221 & 0.372 & 85.3 \\
Inland provinces & 0.264 & 0.489 & 21.6 \\
Rural & & & \\
Coastal provinces & 0.375 & 0.456 & 20.3 \\
Inland provinces & 0.403 & & \\
\hline
\end{tabular}


Table 3 - Poverty headcount by regions (\%)

\begin{tabular}{l|c|c|c|c|c|c}
\hline \multirow{2}{*}{} & \multicolumn{2}{|c|}{ All provinces } & \multicolumn{2}{c|}{ Coastal provinces } & \multicolumn{2}{c}{ Inland provinces } \\
\cline { 2 - 7 } & 1989 & 2004 & 1989 & 2004 & 1989 & 2004 \\
\hline Total & 35.5 & 17.5 & 27.8 & 9.1 & 40.0 & 22.4 \\
Urban & 22.7 & 13.5 & 15.9 & 5.7 & 26.9 & 18.2 \\
Rural & 42.0 & 19.5 & 34.1 & 10.8 & 46.5 & 24.4 \\
\hline
\end{tabular}

Note: 1.5 dollars-a-day (Purchase Power Parity, 1993 international price) translates into 830 yuans for urban areas and 639 yuans for rural areas, 1989 price. 
Table 4 - Decomposition of distribution shifts: growth and distributional effects on poverty reduction, 1989-2004

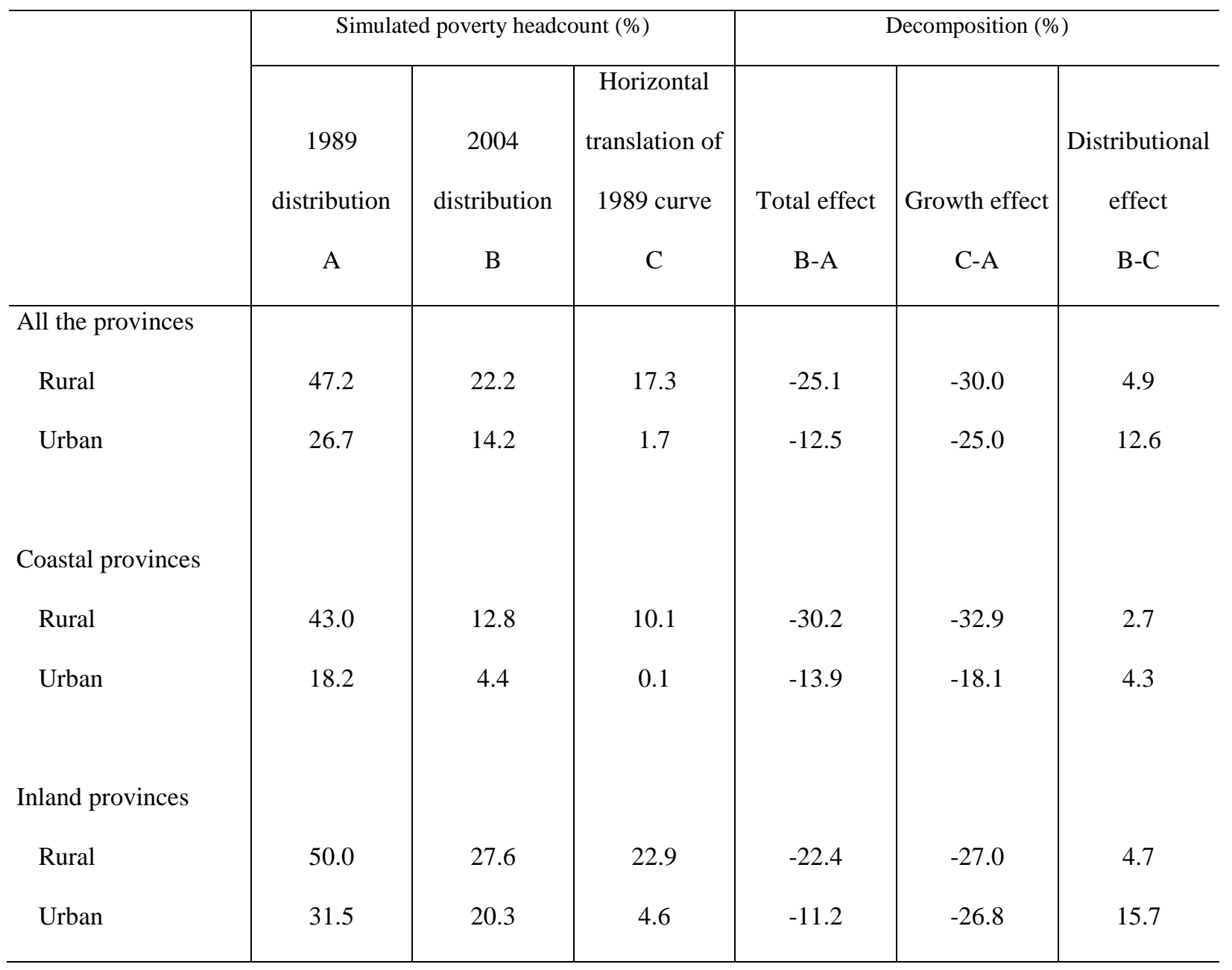


Table 5 - Estimation of income equations

Dependant variable: logarithm of real household per capita income

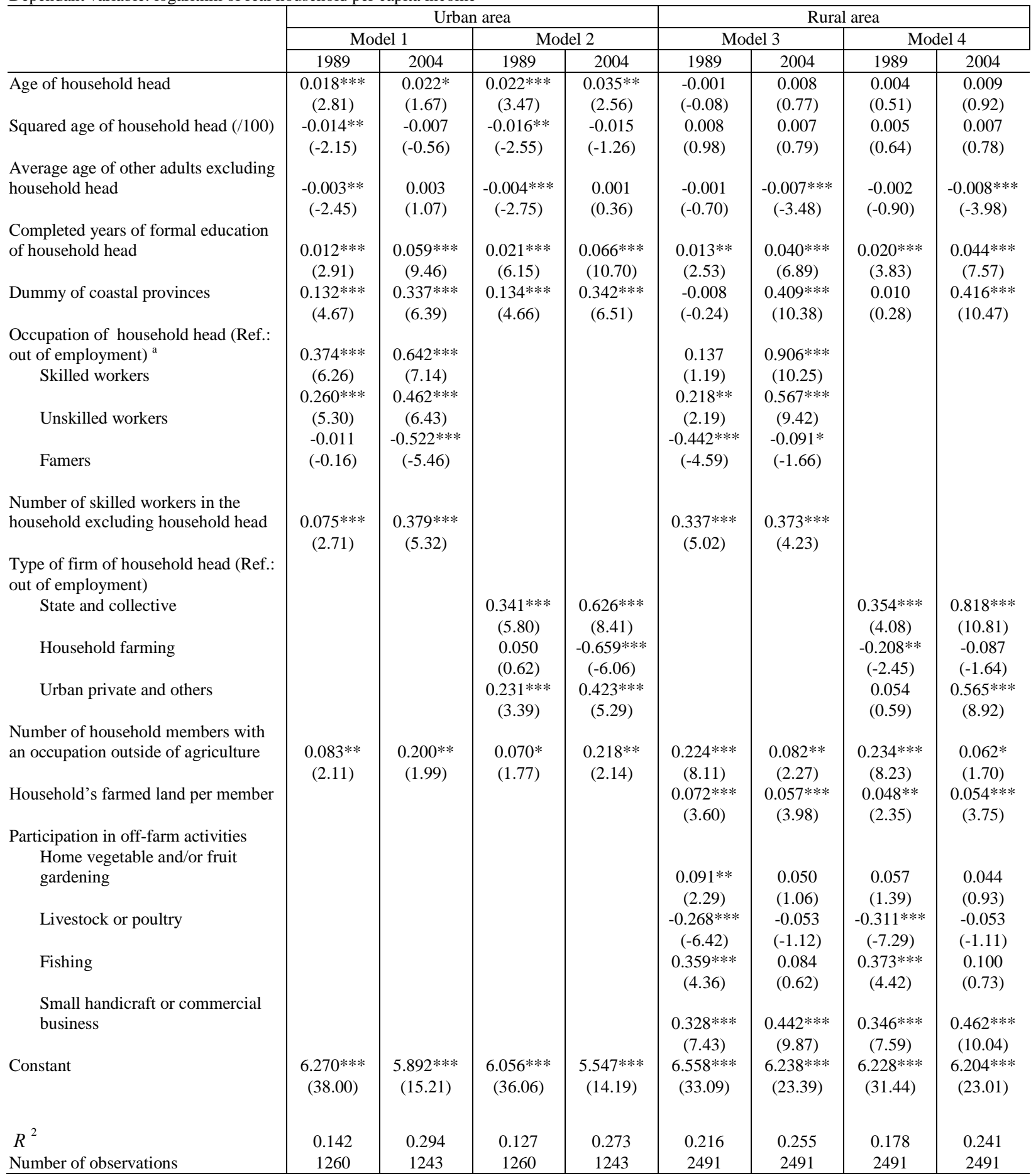

Notes: (a) Skilled workers: Senior professional/technical personnel (doctor, professor, lawyer, architect, engineer, etc.); Professional/technical personnel (midwife, nurse, teacher, editor, photographer, etc.); Administrator/executive/manager, factory manager, government official, section. Unskilled workers: Office staff (secretary, office helper, etc.); Technical, skilled worker (foreman, craftsman, etc.); Non-technical, non-skilled worker (laborer); Service worker; Other occupations (army, police, etc.). Famers: Farmer, fisherman, hunter, logger, etc.

The t-students are presented in parentheses. $* *$ indicates coefficient significant at $1 \%$ level; ** indicates coefficient significant at $5 \%$ level; $*$ indicates coefficient significant at $10 \%$ level. 
Table 6 - Decomposition of per capita income growth between 1989 and 2004

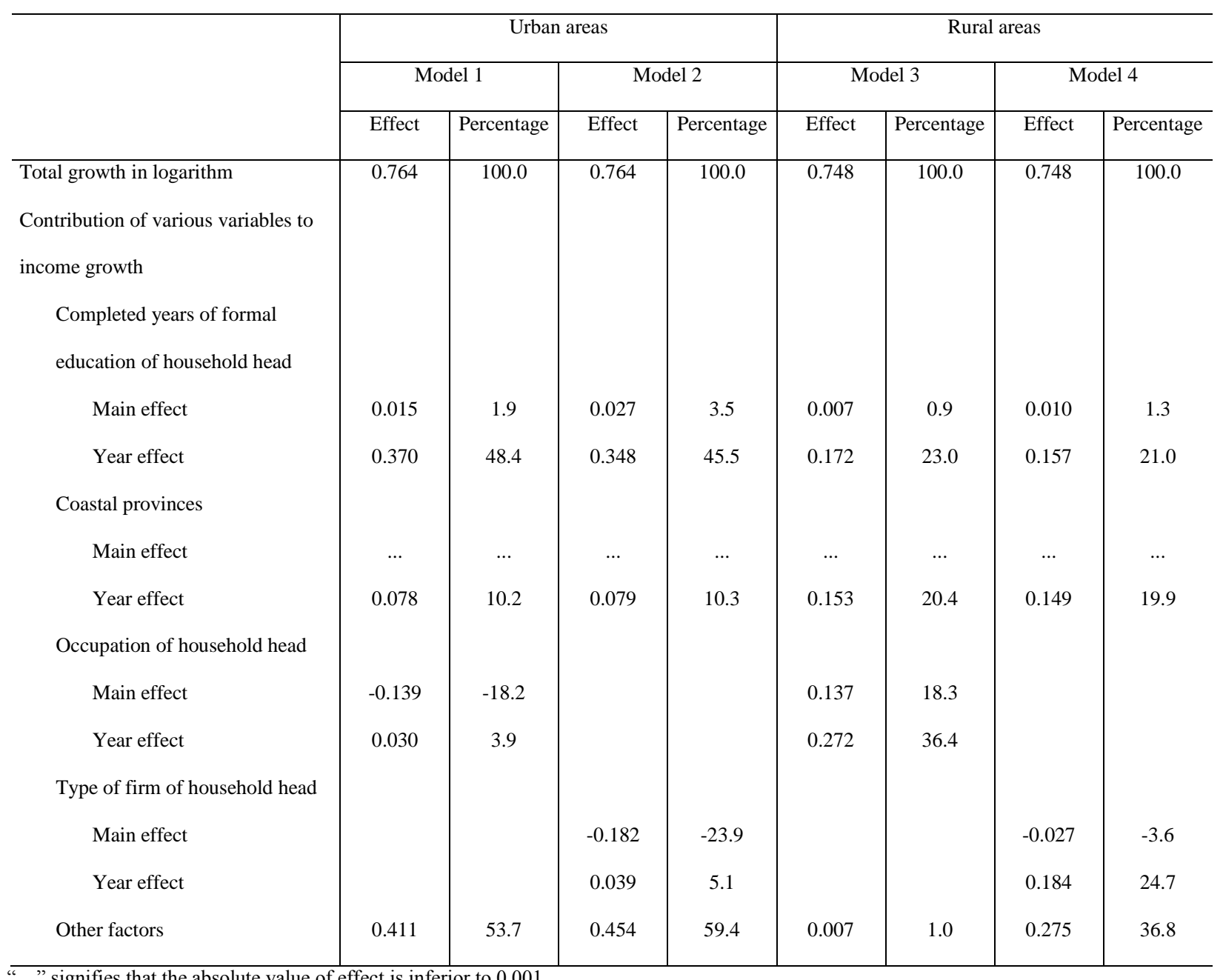

“..." signifies that the absolute value of effect is inferior to 0.001 . 